\title{
FUNCTIONAL TRAITS AND PLASTICITY OF PLANTS IN ECOLOGICAL RESEARCH AND EDUCATION
}

\author{
CECHY FUNKCJONALNE I PLASTYCZNE ROŚLIN \\ W BADANIACH EKOLOGICZNYCH I EDUKACJI
}

\begin{abstract}
Plant functional traits are any morphological, physiological and phenological features, which indirectly affect plant fitness through their three basic components of plant individual performance - growth, reproduction and survival. These features represent also a keystone for plant functional groups, which are similar in three aspects - function on the level of organism, response to environmental factors and effect on ecosystems. Functional approach in ecology and vegetation study enables to evaluate plant communities on the base of species function in a community, and to relate functional structure of plant communities to particular environmental gradients. Species plasticity has many aspects that mirror species adaptations to the environmental conditions and which then also translate into functional structuring of plant communities. This approach is thus a novel and exciting mode how to carry on plant ecology, both in research and education at universities.
\end{abstract}

Keywords: adaptation, functional ecology, functional groups, plant communities, phenotypic plasticity, vegetation

\section{Introduction}

Vegetation, a basic and important component of the natural environment, has an irretrievable function. Ecological functions of vegetation are important from the aspect of the whole ecosystem function, the maintenance of its structure and diversity and for the ecological stability. When evaluating ecological functions of plant communities it is necessary to start with the evaluation of vegetation, its individual components, its basic characteristics and its relationships with the environment [1]. The different aspects of the vegetation study (ie phytocenological, ecological, productional and functional) present a good presumption for the understanding of relationships between individual plant populations within communities and their relationships with the abiotic environment. The basic studies of vegetation structure serve then as a baseline for finding the dependence of plant communities from the important environmental gradients, and eventually for modelling of the future vegetation development. Functional approach of studying vegetation

\footnotetext{
${ }^{1}$ Department of Soil Science, Faculty of Natural Sciences, Comenius University in Bratislava, Mlynská dolina, Ilkovičova 6, SK-842 15 Bratislava, Slovak Republic, phone +421260296340

*Corresponding author: masarovicova@fns.uniba.sk
} 
and its relationships with environment evaluates plant communities on the base of species function in a community mediated through functional traits [2].

Functional ecology thus joins the approaches of physiological ecology, population ecology and ecology of plant communities, including also environmental conditions. It presents a tool for answering important ecological questions upscaling from the ecosystem, to the landscape and eventually to the biome. Here we review the basic information on key plant functional traits, their connection to adaptations to particular environmental conditions as well as their connection to plant plasticity, in particular the variability and adaptability of plants under different and/or changing environmental conditions.

\section{Plant functional traits}

According to Violle et al [2] plant functional traits are any morphological, physiological and phenological traits, which indirectly impact plant fitness via their effects on three fundamental components of plant performance - growth, reproduction and survival. Initially, Hodgson et al [3] divided functional traits into "soft" and "hard" traits. "Soft" traits were characterized as surrogates of the function of interest that were less difficult and/or expensive to obtain, such as specific leaf area, leaf water content and leaf dry mass, plant height, relative length of root, number or mass of seeds [3-5]. "Hard" traits were characterized as those that captured the function of interest, but which were either difficult or expensive to measure, as for example photosynthetic, respiration, transpiration or growth rates, plant water potential, water use efficiency or stomata conductance [3-5]. However, the difficulty and expense of a measurement might depend on one's amount of help and funding available. Reich et al [6] in a project GLOBNET (175 study sites and 2021 plant species) proved that physiological "hard traits" (photosynthetic capacity) could be predictable from a combination of "soft traits" (specific leaf area, leaf persistence, content of $\mathrm{N}$ and $\mathrm{P}$ in a leaf), qualitative traits (growth form and leaf phenology) and meteorological data (mean year temperature, mean year precipitation, mean year air humidity and irradiance). Functional traits of plants express not only their adaptation to the environment and use of resource (irradiance, water, nutrition, temperature), but they are also in a direct relationship with the species and functional composition of plant communities. Plant functional traits present a novel and exciting approach how to carry on plant ecology and how to enable linking of processes observed on plant individuals to plant population dynamics, species distribution patterns and their coexistence, community assembly, and finally, to ecosystem functioning. In order to understand the role of plant functional traits for population and community functioning, Majekova [7-9] used approaches that ranged from an observation study on an in situ gradient, through experimental approaches that modulated and tested effects of specific environmental factors, to an eco-physiological approach that enabled to look deeper inside the functioning of plant individuals.

\section{Plant functional groups}

Functional groups of plants can be characterised as the groups that have similar function on plant level, similar response to environmental factors and/or similar effect on ecosystems and biomes [10-12]. These similarities are based on the fact, that plants of one functional group possess a set of similar fundamental functional traits [4, 5, 13]. Additionally, one functional group can be formed by taxonomically unrelated species. For 
example, in the case of specific leaf area, one plant functional group can be formed by different plant species all having both high SLA values and similar response to environmental conditions (eg light availability).

\section{Plasticity of plants}

Plants can change their development, physiology and life history depending on the environmental conditions. These responses of plants are specific and presented through morphological, anatomical and physiological characteristics. In the last years, attention was paid mainly to the fundamental characteristics of plants related to their variability and adaptability, specifically to the genotypic, phenotypic, morphological and physiological plasticity. It has been emphasized that phenotypic plasticity facilitates plants to maintain their function in a community and their fitness under different climatic conditions, and thus influence the expansion and selection of plants (in detail see Masarovicova et al [14]). One genotype can form different phenotypes in different environmental conditions. This fundamental attribute of all living organisms, including plants, is known as the phenotypic plasticity. Recently it was confirmed that plants are plastic from many aspects: morphological, anatomical, physiological and in their growth or reproductive attributes. Phenotypic plasticity plays an important role in both ecological distribution and evolutionary diversification of plants (eg Sultan [15]). Responses of plants to particular environmental conditions are specific and present characteristics (traits, features) that arose among genotypes, species or populations. This view presents a new perception induced into the definition of genotype "as a repertoire of environmentally contingent phenotypic possibilities or norm of reaction, rather than a blueprint for a single fixed outcome" $[16,17]$.

Plasticity of plants was the most intensively studied in species that responded to environmental changes via their growth and development. The pioneer studies in this area focused on the observation of plant height, number of shoots or length of internodes. Only later, the re-allocation of biomass into individual plant organs, relative growth rate or assimilation rate were measured and studied [18-20]. Current studies emphasize more the evolutionary, ecological and developmental aspects of plasticity. For example, Gedroc et al [21] observed a re-distribution of biomass from shoots into the root system in the conditions of water stress, or higher values of LAR (ratio between leaf area and plant biomass) in the conditions of lower irradiance. These specific adjustments and developmental plasticity can partially compensate the inevitable reduction of growth and biomass formation of plants in the conditions of resources limitations, such as water, nutrition or irradiance. In different environmental conditions plants responded also via physiological processes (physiological plasticity), such as photosynthetic, respiration and transpiration rates, stomata conductance, mineral nutrients uptake, etc. [22]. In the past, plasticity in the relationship to the environmental resources was studied on the level of a shoot to root ratio (distribution of biomass into shoot and root). At present, the properties of a shoot and root are investigated in more details - leaf area, specific leaf area, root length, LAR (ratio between leaf area and plant biomass, which directly influences photosynthetic active radiation), RLR (ratio between total plant height and total plant biomass, which indicates capacity of the root system for mineral nutrient uptake) [23]. Under conditions of nutrients deficit, for example, plants adapt a strategy with shorter life cycle and higher number of inflorescences. 


\section{Relationship among plasticity, physiological processes and ecological factors}

Plasticity of plants is also connected with the acclimation of physiological processes (photosynthesis, respiration, distribution of biomass into different plant organs) to environmental factors, such as irradiance and water supply. However, relatively small plasticity of one characteristic can be a consequence of a large plasticity of another characteristic. For example, a small morphological plasticity (shoot length) of an Alpine species Stellaria longipes is a consequence of a large physiological plasticity (ethylene production). Both characteristics are directly related to the same environmental factor (stress by a strong wind) and the newly formed phenotype has a direct effect on the overall fitness of this species [24]. In addition, a large morphological plasticity in biomass distribution into the shoot and root in the relationship to the nutrients availability and irradiance was manifested in a small plasticity of growth rate, so that growth rate varied relatively slightly in different environmental conditions. Moreover, the competition ability of a given species in a community is not negligible. For example, species of the late successional stages have a higher tendency to adjust their photosynthetic characteristics to more shaded conditions than species of the early successional stages [25]. Typical example is an extension of shoots under shade conditions. Shade also reduce branching of dicotyledonous species and induce (stimulate) tillering of monocotyledonous species (graminoids). According to Deregibus et al [26] this plastic reaction to the environmental condition is probably important in the light of given species canopy with the neighbouring plants. Fast growing species (compared to slow growing species), occurring more in nutrient rich soils, have more plastic characteristics (mainly photosynthetic characteristics and shoot extension rate) in response to shade, wind speed or standing canopy. These plants often have similar changes in parameters such as root mass ratio and stem mass ratio that slow the growth of species [27]. However, it should be stressed that no individual eco-physiological characteristic exists that should provide a competition prevalence of a given genotype. The consequence of competition under drought, flood, frost or fire could be that some of the genotype can overcome these events, but others do not survive and at last become locally extinct.

\section{Conclusions}

Plant functional traits and plasticity of the plants are current and exciting approaches how to carry on plant ecology, both in research and in education at universities. These approaches enable scientists and teachers to link processes observed on plant individuals to plant population dynamics, species distribution patterns and their co-existence, community assembly, and finally, to ecosystem functioning. Functional approach to vegetation characterization and its relationship with environment enables to evaluate plant communities on the base of species function in a community. Functional ecology thus joins the approaches of physiological ecology, population ecology and ecology of plant associations, including also environmental effects on ecosystems. These novel approaches provide useful tools for answering important ecological question in ecosystem, landscape and biome measure. 


\section{Glossary (according to Masarovicova et al [14])}

Adjustment: Realignment of features and performance of the plants with environmental conditions so that they can survive.

Adaptation: Process by which the plants during evolution accommodate (or resist) to environmental condition through genetically conditioned morphological and physiological changes. The term of "adaptation" has wider meaning that term of adjustment.

Adaptability: Ability to accommodate on variable environment. However, the measure of tolerance cannot be exceeded.

Adaptive plasticity: Phenotypic plasticity that increases the global fitness of a genotype.

Acclimation: Set of physiological (not genetic) responses on environmental conditions. Change of certain environmental factor can improve survive of the plant.

Fitness: The fitness of a plant individual is taken as the relative abundance and success of its genes (often measured as the number of surviving offspring) over multiple generations. In many cases, especially with large or long-lived species, direct estimates of fitness are not feasible and total biomass, seed number, biomass or growth rate of a single generation are used as proxies.

Genome (genotypic) plasticity: A change in genome structure or organization associated with environmental signals, leading to the evolution of new phenotypes, might result from mutational hotspots, genome expansion, transposable elements or somatic recombination.

Genotype: To report to a genotype we do so in a population genetic sense, not in reference to a molecular sequence of a single gene, but to the complete genome.

Intraspecific trait variability: The overall variability of trait values expressed by individuals within a species.

Morphological plasticity: A change in morphology (shape and size) plant organs (mainly leaf and root) that is important for utilization of environmental resources ( $e g$ water, nutrients, light and temperature).

Phenotype: The appearance or characteristics of an organism resulting from both genetic and environmental influences (genotype + environment = phenotype). All organisms have a phenotype not just those expressing a mutation in a given gene of interest.

Phenotypic plasticity: The range of phenotypes a single genotype can express as a function of its environment. Originally this feature was apprehended in the context of ontogeny of the plant. At present phenotypic plasticity include changes occurring in the adult plants as their behaviour under certain environmental conditions.

Functional traits: Any trait, that is directly or indirectly affecting individual performance and fitness of species.

Functional types: Categorical assessments enabling plant species to be grouped according to functional position in a community (or ecosystem) and their use of resources. These plants have similar responses to the environmental factors and/or similar effects on ecosystems and biomes. The plants of one functional group have set of similar key functional traits. For example, classification based on growth form ( $e g$ herb, grass, shrub), photosynthetic pathway, leaf longevity or nitrogen fixing status.

Physiological plasticity: A change in physiological processes associated with environmental changes, leading to the formation of new phenotypes. 
Plasticity: Ability of a single genotype to exhibit a range of different phenotypes in response to variation in the environment. In response to variable environmental conditions the plant can adjust its features through morphological traits and/or physiological processes.

Resilience (elasticity): Ability of plant to return to the original state after being action, perturbation or disturbance. Plants (ecosystems) resist to the damage and after deviation fast recovery (regeneration) occurred.

Trait: Any morphological, physiological, phenological or behavioural characteristic that can be measured at the individual level.

\section{Acknowledgments}

This contribution was financially supported by the Grant Agency VEGA (Grants No.1/0218/14 and 1/0365/14) and from the Slovak Research and Development Agency (Grant No. APVV-0866-12).

\section{References}

[1] Eliáš P. Ecological and social functions of vegetation. Ekológia (Bratislava). 1983;2:93-104. DOI: 147.213.211.222/node/3806.

[2] Violle C, Navas ML, Vile D, Kazakou E, Fortunel C, Hummel I, et al. Let the concept of trait be functional! Oikos. 2007;116:882-892. DOI: 10.1111/j.0030-1299.2007.15559.

[3] Hodgson JG, Wilson PJ, Hunt R, Grime JP, Thompson K. Allocating C-S-R plant functional types: a soft approach to a hard problem. Oikos. 1999;85:282-294. DOI: 10.2307/3546494.

[4] Weiher E, van der Werf A, Thompson K, Roderick M, Garnier E, Eriksson O. Challenging Theophrastus: A common core list of plant traits for functional ecology. J Veg Sci. 1999;10:609-620. DOI: $10.2307 / 3237076$.

[5] Cornelissen JHC, Lavorel S, Garnier E, Diaz S, Buchmann N, Gurvich DE, et al. A handbook of protocols for standardised and easy measurement of plant functional traits worldwide. Aust J Bot. 2003;51:335-380. DOI: 10.1071/BT02124.

[6] Reich PB, Wright IJ, Lusk CH. Predicting leaf physiology from simple plant and climate attributes: A global GLOPNET analysis. Ecol Appl. 2007;17:1982-1988. DOI: 10.1890/06-1803.1.

[7] Májeková M, de Bello F, Dolezal J, Lepš J. Plant functional traits as determinants of population stability. Ecology. 2014;95(9):2369-2374. DOI: 10.1890/13-1880.1.

[8] Májeková M., Janeček Š, Mudrák O, Horník J, Janečková P, Bartoš M, et al. Consistent functional response of meadow species and communities to land-use changes across productivity and soil moisture gradients. Appl Veg Sci. 2016 (in press).

[9] Májeková M, Vykouková I, Masarovičová E. Leaf turgor loss point in relation to soil moisture and leaf dry matter content. Phytopedon (Bratislava). 2015;14(1):1-6.

[10] Lavorel S, McIntyre S, Landsberg J, Forbes TDA. Plant functional classifications: from general groups to specific groups based on response to disturbance. Trends Ecol Evol. 1997;12:474-478. DOI: 10.1016/S0169-5347(97)01219-6.

[11] Westoby M. A leaf-height-seed (LHS) plant ecology strategy scheme. Plant Soil. 1998;199:213-227. DOI: 10.1023/A:1004327224729.

[12] Lavorel S, Garnier E. Predicting changes in community composition and ecosystem functioning from plant traits: revisiting the Holy Grail. Funct Ecol. 2002;16:545-556. DOI: 10.1046/j.1365-2435.2002.00664.

[13] Diaz S, Cabido M. Plant functional types and ecosystem function in relation to global change. J Veg Sci. 1997;8:463-474. DOI: 10.2307/3237198.

[14] Masarovičová E., Májeková M., Vykouková I. Functional traits and plasticity of the plants. In: Pessarakli M, editor. Handbook of Photosynthesis. Third edition. Boca Raton, FL: CRC Press, Taylor and Francis Group, LLC; 2015 (in press).

[15] Sultan SE. Phenotypic plasticity for plant development, function and life history. Trends Plant Sci. 2000; 5:537-542. DOI: 10.1016/S1360-1385(00)01797-0.

[16] Miklos GLG, Rubin GM. The role of the genome project in determining gene function: insights from model organisms. Cell. 1996;86:521-529. DOI: 10.1016/S0092-8674(00)80126-9. 
[17] Trewavas AJ, Malhó R. Signal perception and transduction: the origin of the phenotype. Plant Cell. 1997;9:1181-1195. DOI: 10.1105/tpc.9.7.1181.

[18] Schlichting CD. The evolution of phenotypic plasticity in plants. Ann Rev Ecol Syst. 1986;17:667-693. http://www.jstor.org/stable/2097012.

[19] Sultan SE. Evolutionary implications of phenotypic plasticity in plants. Evol Biol. 1987;21:127-178. DOI: 10.1007/978-1-4615-6986-2_7.

[20] Bradshaw AD, Hardwick K. Evolution and stress: genotypic and phenotypic components. Biol J Linn Soc. 1989;37:137-155. DOI: 10.1111/j.1095-8312.1989.tb02099.x.

[21] Gedroc JJ, McConnaughay KDM, Coleman JS. Plasticity in root/shoot partitioning: optimal, ontogenetic, or both? Funct Ecol. 1996;10:44-50. DOI: 10.2307/2390260.

[22] Sultan SE, Wilczek AM, Bell DL, Hand G. Physiological response to complex environments in annual Polygonum species of contrasting ecological breadth. Oecologia. 1998;115:564-578. DOI: $10.1007 / \mathrm{s} 004420050554$.

[23] Ryser P, Eek L. Consequences of phenotypic plasticity vs. interspecific differences in leaf and root traits for acquisition of aboveground and belowground resources. Am J Bot. 2000;87:402-411. http://www.amjbot.org/content/87/3/402.

[24] Emery RJN, Chinnappa CC, Chmielewski JG. Specialization, plant strategies, and phenotypic plasticity in populations of Stellaria longipes along an elevational gradient. Int J Plant Sci. 1994;155:203-219. www.jstor.org/stable/2995565.

[25] Küppers M. Carbon relations and competition between woody species in a central European hedgerow. I. Photosynthetic characteristics. Oecologia. 1984;64:332-343. DOI: 10.1007/BF00379131.

[26] Deregibus VA, Sanchez RA, Casal JJ. Effects of light quality on tiller production in Lolium spp. Plant Physiol. 1983;72:900-902. DOI: 10.1104/pp.72.3.900.

[27] Poorter H, Van de Vijver CADM, Boot RGA, Lambers H. Growth and carbon economy of a fast-growing and a slow-growing grass species as dependent on nitrate supply. Plant Soil. 1995;171:217-227. DOI: 10.1007/BF00010275.

\title{
CECHY FUNKCJONALNE I PLASTYCZNE ROŚLIN W BADANIACH EKOLOGICZNYCH I EDUKACJI
}

\begin{abstract}
Abstrakt: Charakterystyczna funkcjonalność roślin zależy od ich cech morfologicznych, fizjologicznych i fenologicznych, które pośrednio wpływają na kondycję roślin poprzez trzy podstawowe elementy ich indywidualnego rozwoju, tj. wzrost, reprodukcję i przetrwanie. Cechy te stanowią również podstawę funkcyjnych grup roślinnych, które są podobne w trzech aspektach - funkcje na poziomie organizmu, odpowiedź na czynniki środowiskowe i wpływ na ekosystemy. Podejście funkcjonalne w ekologii i w badaniach roślin umożliwia ocenę zbiorowisk roślinnych w oparciu o funkcje gatunków w społeczności i odniesienie funkcjonalnej struktury zbiorowisk roślinnych do poszczególnych gradientów środowiskowych. Plastyczność gatunków ma wiele aspektów, które odzwierciedlają ich przystosowanie do warunków środowiskowych, a które następnie przekłada się także na funkcjonalną strukturę zbiorowisk roślinnych. Takie podejście jest więc nowym i interesującym sposobem rozumienia ekologii roślin, znajdującym zastosowania zarówno w badaniach, jak i w edukacji uniwersyteckiej.
\end{abstract}

Słowa kluczowe: adaptacja, ekologia funkcjonalna, grupy funkcyjne, zbiorowiska roślinne, plastyczność fenotypowa, roślinność 